\title{
Jailhouse Informants and the Need for Judicial Use Immunity in Habeas Corpus Proceedings
}

\author{
Jana Winograde $\dagger$
}

\begin{abstract}
Jailhouse informants who recount their fellow prisoners" "confessions" are often used by the state as witnesses in criminal prosecutions. It has recently become public knowledge that such confessions are easily fabricated. However, many defendants convicted on the basis of allegedly perjured jailhouse confessions remain imprisoned because they lack the mechanism necessary to compel the informant to recant his earlier testimony in habeas corpus proceedings based on false evidence introduced at trial. Without such a mechanism, an informant will invoke his fifth amendment privilege out of fear of a perjury prosecution for the earlier perjured testimony. In this Comment, the author argues that California courts have the power, and indeed the obligation, to grant immunity to jailhouse informants in this context. The author justifies this grant of immunity on several bases. First, she argues that the court, and not the prosecutor, is the logical and likely source of this immunity grant. Second, the grant would further the legislative purpose of the habeas corpus writ. Finally, the author concludes that such a grant of immunity correctly balances the prisoner's constitutional rights to fairness of process against the state's interest in perjury prosecutions.
\end{abstract}

Society wins not only when the guilty are convicted but when criminal trials are fair; our system of the administration of justice suffers when any accused is treated unfairly. . . . "The United States wins its point whenever justice is done its citizens in the courts." 1

\section{INTRODUCTION}

A jailhouse informant is an inmate, usually awaiting trial or sentencing, who claims to have heard another prisoner make an admission about his case. The informant then reports the other prisoner's admission to the authorities in the hope of trading his testimiony for better treatment or leniency in sentencing. Because the informant's testimony may be

$\dagger$ B.A. 1986, University of California, San Diego; J.D. 1990, Boalt Hall School of Law, University of California, Berkeley.

1. Brady v. Maryland, 373 U.S. 83,87 (1963). 
completely fabricated, the use of jailhouse informants to obtain convictions may be "one of the most abused aspects of the criminal justice system."2 Despite criticism of this practice, its use is widespread. In fact, the Los Angeles District Attorney's office has used jailhouse informants to obtam convictions in at least 120 crimmal cases over the past ten years. $^{3}$

In October 1988, Leshe White, a jailhouse informant employed by the Los Angeles District Attorney's office for more than ten years, demonstrated for the Los Angeles Sheriff's Department that he could convincingly fabricate a fellow inmate's murder confession. ${ }^{4}$ White proved that a jailhouse informant can gather enough information about a particular crime to testify agamst a defendant at trial without ever having met the defendant. ${ }^{5}$ Indeed, White and several other informants regularly used by the District Attorney's office have admitted to giving false testimony about various defendants' jailhouse confessions in order to obtain lenient treatment in their own cases. ${ }^{6}$ Because a number of convicted defendants may be serving lengthy sentences, or perhaps sitting on death row, as a result of the State's use of perjured testimony, the District Attorney's office has launched an exhaustive investigation into every conviction from the past ten years in which a jailhouse informant testified. $^{7}$

2. Rohrlich, Review of Murder Cases is Ordered, L.A. Times, Oct. 29, 1988, pt. I, at 1, col. 5 (statement of Richard G. Hirsch, former president of California Attorneys for Criminal Justice).

3. A Snitch's Story, TIME, Dec. 12, 1988, at 32.

4. Rohrlich, Review of Murder Cases is Ordered, L.A. Times, Oct. 29, 1988, pt. I, at 1, col. 5.

5. White demonstrated the process as follows: The informant first gathers data about a particular defendant over the jailhouse phone from unsuspecting law enforcement authorities. Then, posing as a prosecutor, police officer, or bail bondsman, the informant calls law enforcement offices and asks about the crime, trying to acquire the kinds of information that would not be found in the newspaper. Through such questioning the informant may elicit the victim's name, the exact address where the crime occurred, the time the crime was committed, and the location of the arrest.

In order to create a written record of his supposed contact with the defendant, the informant then arranges to share a bus ride with the unsuspecting defendant. For example, he may call a prosecutor he knows in a suburban courtlouse at which the defendant is scheduled for a court appearance. The informant tells the prosecutor that he has important information to convey. The prosecutor then arranges transportation to the suburban courtlouse, putting the informant and his intended victim on the same bus. The informant need never speak to the implicated defendant. Id.; see also $A$ Snitch's Story. TIME, Dec. 12, 1988, at 32.

6. Cody, Questions Raised About Testimony of Jail Informants, L.A. Daily J., Nov. 2, 1988, at 1, col. 5. Powerful incentives and rewards are pronised to informants in exchange for their testimony. In exchange for the testimony of one innate informer, prosccutors reportedly relocated the informant, found him a job, and paid his rent for a year. Id. Leslie White claims to have received two seven-day furloughs froin prison while serving a twelve-1nonth jail term for a parole violation. White was also transferred froin county jail to a more comfortable suburban jail where privileges such as stereo-equipped jail cells and furloughs are easier to obtain. Kowsky \& HillHoltzman, A Snitch Inside Saves Time, L.A. Herald Examiner, Nov. 17, 1988, at A1, col 2.

7. See Cody, Jailhouse Informants: The D.A.'s Ethical Bind, L.A. Tines, Nov. 13, 1988, pt. III, at 3, col. 1; see also The Bar Looks at Informants, L.A. Times, Dee. 1, 1988, pt. II, at 6, col. 1. 
The most important issue raised by the use of jailhouse confessions is how to obtain a new trial for those prisoners who have been convicted on the basis of such perjured testimony. The logical solution is for the prisoner to file a petition for a writ of habeas corpus on the grounds that "false evidence substantially material or probative on the issue of guilt or pumshment was introduced at trial." 8 The writ would allow the prisoner to attack his conviction collaterally if he could present evidence that his purported jailhouse confession was actually fabricated by the prosecution's witness. ${ }^{9}$ Because the District Attorney's office tends to use jailhouse informant testimony only when a case is "weak,"10 a prisoner who was able to provide evidence that the testimony was perjured should obtam a new trial.

Although the solution seems clear, a prisoner may find it difficult to provide the necessary evidence to attack his conviction. In order to prove that the informant perjured himself at trial, the prisoner must elicit the informant's admission at an evidentiary hearing on the habeas writ. However, since such an adimission would subject the informant to prosecution for perjury and added jail time, he will likely refuse to testify. ${ }^{11}$ If the prisoner then attempts to subpoena the informant to testify at an evidentiary hearing, the informant will probably invoke his fifth amendment privilege agamst self-imcrimination. ${ }^{12}$ Without a inechanism to compel the informant to testify, the convicted defendant will be unable to prove that the most daniaging evidence used aganist him at trial was perjured.

The problems presented by an informant's imvocation of the fifth amendment are not insurmountable. For example, when a witness for

8. Cal. Penal CODE $\S 1473$ (West 1982). This section provides:

(a) Every Person unlawfully imprisoned or restrained of his liberty, nnder any pretense whatever, may prosecute a writ of habeas corpus, to inquire into the cause of such imprisonment or restraint.

(b) A writ of habeas corpus may be prosecuted for ....

(1) False evidence that is snbstantially material or probative on the issue of guilt or punishment was introduced against a person at any hearing or trial relating to his incarceration.

9. This Comment will only address a defendant's ability to prosecute a writ of habeas corpus after a final conviction. If a defendant learns of the perjured testimony before a final judgment is rendered in his case, he may make a motion for a new trial based on the existence of newly discovered evidence. CAL. PENAL CODE § 1181(8) (West 1985).

10. Apparently, the Los Angeles District Attorney's office was aware of the unreliability of certain jaillouse informants yet continued to use their testimony in otherwise "weak" cases in order to obtain convictions. See Hill-Holtzman, DA's Office Got Word on Snitches, L.A. Herald Examiner, Dec. 7, 1988, at Al, col. 1. The implications of possible prosecutorial imisconduct are discussed at infra note 99 .

11. See Rohrlich, Jail Inmate Says He Lied in Role as Informant, L.A. Times, Dec. 1, 1988, pt. II, at 1 , col. 1 (White refused to identify specific instances of perjury without immumty from prosecution).

12. U.S. CoNST. anend. $V$ ("No person ... shall be compelled in any criminal case to be a witness against himself."). 
the prosecution invokes his fifth amendinent right not to testify, the state may grant the witness immunity fron any later prosecution based on his present testimony and then request that the court coinpel the witness to testify. ${ }^{13}$ The Suprenie Court has ruled that such prosecutorial grants of immunity adequately protect a witness' fifth anendnent rights. ${ }^{14}$

In the jailhouse informant case, however, the prosecutor may be unwilling to grant immunity to the informant. Although one might argue that allowing the informants to testify without fear of prosecution would better serve justice, prosecutors know that the public is aware and outraged about the "jailhouse informant scandal."15 Evidently reacting to this outrage, one Los Angeles Deputy District Attorney has referred to the idea of granting these informants imnuunity as "preposterous."16

Confronted with an unwilling prosescutor, the prisoner inay wish to coinpel tlie grant of immunity. The Suprene Court has never addressed whether criminal defendants have a general right to compel prosecutorial grants of immunity to defense witnesses. The bulk of the case law, both state and federal, rejects such a notion, even where the grant of immunity seenis "fair." 17 However, there are a few cases in which courts have found that due process requires the state to grant immunity to a defense

13. . All 50 states and the Federal Government have enacted immunity provisions. See, e.g., 18 U.S.C. $\$ \S 6001-6005$ (1988); GA. CODE ANN. $\$ 38-1715$ (Harrison 1981); OHIo REV. CODE ANN. $\S$ 2945.44 (Anderson 1987). This Comment will only address the California immumity statute, CAL. PENAL CODE $\S 1324$ (West 1982), and will use federal cases by analogy where pertinent.

14. Kastigar v. United States, 406 U.S. 441, 453 (1972) (holding that state and federal governments may constitutionally compel testimony from a witness who invokes his fifth amendment privilege, by granting the witness "use immunity" only). Courts may grant two types of immunity: "transactional immunity" and "use immunity." Transactional immunity protects the witness against prosecution for any matter about which he might testify under the grant of immunity. Use immunity only "protects the witness from having his testimony, or any fruits derived therefrom," used against him. Note, A Re-Examination of Defense Witness Immunity: A New Use for Kastigar, 10 HARv. J. oN LEgIS. 74, 75 (1972). See also Ullman v. United States, 350 U.S. 422 (1956) (statute that compels testimony by granting transactional immunity is constitutional); Brown v. Walker, 161 U.S. 591 (1896) (same).

15. See, e.g., The L.A. Daily J., Nov. 15, 1988, at 6, col. 3 ("Letters from our Readers").

16. Rohrlich, Jail Inmate Says He Lied in Role as Informant, L.A. Times, Dec. 1, 1988, pt. II, at 1 , col. 1. Although the Deputy District Attorney stated that the time for considering immunity would be when a specific case was brought before a judge for reconsideration, he gave no indication that a grant of immunity would be any less preposterous at that time. Id.

17. See, e.g., United States v. Drape, 668 F.2d 22, 26 (1st Cir. 1982) (a defendant does not have an absolute right to obtain immunity for defense witnesses because such a right "would interfere with the exclusive authority of [prosecutors] to initiate criminal proceedings"); United States v. Turkish, 623 F.2d 769 (2d Cir. 1980) (there is no general requirement under the due process clause that defense witnesses be given immunity whenever it seems fair to do so), cert. denied, 449 U.S. 1077 (1981); United States v. Allesio, 528 F.2d 1079 (9th Cir.) (holding that the government cannot be compelled to grant immunity to a prospective defense witness), cert. denied, 426 U.S. 948, reh'g. denied, 429 U.S. 873 (1976); People v. Martin, 150 Cal. App. 3d 148, 197 Cal. Rptr. 655 (1983) (trial court's refusal to grant immunity to defense witnesses was not abuse of discretion), vacated on other grounds, 44 Cal. 3d 1, 744 P.2d 374, 241 Cal. Rptr. 263 (1987). 
witness. ${ }^{18}$ In addition, several cases recognize that the court has inherent authority to grant a defense witness immunity in certain situations. ${ }^{19}$

This Comment will argue that the Los Angeles jailhouse informant scandal presents a situation where the court in a habeas corpus proceeding should itself grant use immunity to an informant who invokes his fifth amendinent privilege when asked whether he perjured himself at trial. ${ }^{20}$ Section I will discuss the origins of the writ of habeas corpus and the procedure for obtaining the writ. Then, Sections II and III will present two independent arguments defense counsel might use to convince a court to grant use immunity to a witness when the prisoner is attacking his conviction collaterally through a writ of habeas corpus.

Section II will discuss Califorma precedent holding that a court in a civil proceeding may grant use immunity to a witness to prevent any information divulged by this witness from benig used in a later criminal proceeding. The court's authority to grant immunity in this context rests on the premise that such a grant would further the legislative purpose of

18. Government of Virgin Islands v. Smith, 615 F.2d 964, 969, 971 (3d Cir. 1980) (vacating defendant's sentences and remanding because prosecution's refusal to consent to imumumity for witnesses who would have exculpated defendants was prosecutorial misconduct and because trial court's refusal to grant immurity itself violated defendant's due process rights); Urited States v. Herman, 589 F.2d 1191, 1199-1200, 1203-04 (3d Cir. 1978) (suggesting in dicta that upon defendant's showing of inisconduct, a court could require the prosecution either to grant use immunity to defense witnesses upon retrial or accept acquittal), cert. denied, 441 U.S. 913 (1979); Umited States v. Morrison, 535 F.2d 223, $228-29$ (3d Cir. 1976) (prosecutor's intimidation of a defense witness violated the defendant's due process rights, and upon retrial the prosecution must either request use immumity for the witness or accept a new trial).

19. See Virgin Islands, 615 F.2d at 969-70; Herman, 589 F.2d at 1191; Daly v. Superior Court, 19 Cal. 3d 132, 560 P.2d 1193, 137 Cal. Rptr. 14 (1977); People v. Superior Court (Kaufman), 12 Cal. 3d 421, 525 P.2d 716, 115 Cal. Rptr. 812 (1974); Byers v. Justice Court, 71 Cal. 2d 1039, 458 P.2d 465, 80 Cal. Rptr. 553 (1969), rev'd on other grounds sub nom. California v. Byers, 402 U.S. 424 (1971).

20. This Comment does not argue that defense witness immunity is compelled in every case in which it seems fair to do so. That notion has uniformly been rejected by both state and federal courts, see supra note 17, and thoroughly addressed by other commentators. See, e.g., Comment, Right of the Criminal Defendant to the Compelled Testimony of Witnesses, 67 CoLum. L. REv. 953, 973, 977 (1967) (arguing for legislation which allows a defendant to obtain defense witness immunity and examining the court's power to grant immunity in the absence of legislation); Note, Defense Witness Immunity in New York, 71 CoRNELI L. REV. 890, 911-17 (1986) (analyzing the development of defense witness immunity in New York and suggesting judicial and legislative adoption of a two-stage in camera hearing procedure to evaluate immumity requests); Note, supra note 14 (arguing that a defendant has a due process right to defense witness immunity); Note, The Sixth Amendment Right to Have Use Immunity Granted to Defense Witnesses, 91 HaRv. L. REV. 1266 (1978) (arguing that a defendant's sixth amendment right to compulsory process requires the state to grant use immunity to defense witnesses unless such immunity would significantly burden the state); Note, "The Public Has a Claim to Every Man's Evidence": The Defendant's Constitutional Right to Witness Immunity, 30 STAN. L. REV. 1211 (1978) (authored by Donald Koblitz) (arguing that defendants have a right to defense witness immunity under due process and the sixth amendment, and that the right should be implemented through a balancing test to take place at an in camera hearing). 
the civil statute without unduly hampering any later criminal prosecutions. This Section will argue that because habeas corpus proceedings are actually civil proceedings, California courts have both the power and the obligation to grant immunity to jailhouse informants who invoke their fifth amendinent privilege in such proceedings. Further, Section II will show that because a habeas proceeding is not a "felony proceeding" within the neaning of California Penal Code Section $1324,{ }^{21}$ a prosecutor in Califorina may not have the statutory power to request a grant of immunity. ${ }^{22}$ Thus the argunent $\mathrm{n} 1$ favor of judicial use immunity is strengthened since, im this context, the court is the only source of use immunity.

Section III will present the second argument in favor of judicial use immunity-that the prisoner's due process and coinpulsory process rights conipel sucl a grant. First, Section III will present Suprenie Court precedent delineating the defendant's due process and compulsory process rights im a criminal proceeding. This Section will show that a crininal defendant has the right to present material, relevant, and exculpatory evidence unless there is a strong, countervailing state interest. This Section will then demonstrate how certain courts have applied this doctrine im the context of defense witness inimunity.

Next, Section III will present the Supreine Court precedent recognizing that constitutional rights, especially those guaranteed by the due process clause, apply in postconviction proceedings. Although states have no constitutional obligation to provide a mechanism for collaterally attacking a conviction, once the right is established by state law, the convicted defendant is entitled to fundanrental fairness of process within the proceedings. Finally, Section III will argue that the prisoner's interest in presenting exculpatory evidence in a habeas proceeding outweighs the state's interests in prosecuting an inforinant for perjury. Thus a court's refusal to grant immunity to a jailhouse informant deprives the prisoner of his constitutional rights.

It is important to note that a judicial grant of use inınunity would

21. The District Attorney may request immunity "[i]n any felony proceeding or in any investigation or proceeding before a grand jury for any felony offense . . . ." Cal. PENAL CoDE section 1324 (West 1982).

It is important to note that although the District Attorney in California has the power to request use immumity for prosecution for past perjury under section 1324, the witness is still liable for any future perjury committed while the witness is testifying under tle grant of immunity. People v. Baker, $88 \mathrm{Cal}$. App. 3d 115, 123-24, $151 \mathrm{Cal}$. Rptr. 362, 367 (1978) (use immunity compels the witness to testify truthfully and prevents the prosecntor from using the compelled testimony to bring charges against the witness for perjury in prior proceedings); People v. Hathcock, $17 \mathrm{Cal}$. App. 3d 646, 649-50, $95 \mathrm{Cal}$. Rptr. 221, 223 (1971) (npholding conviction for perjury committed while defendant was testifying under grant of use immunity).

22. In re Weber, 11 Cal. 3d 703, 719-20, 523 P.2d 229, 239-40, 114 Cal. Rptr. 429, 439-40 (1974) (attorney general has no authority to grant immunity in habeas corpus proceedings). 
not prevent the state from bringing charges against the immunized informant-witness. ${ }^{23}$ Rather, the state would simply be prevented from using the immunized testimony, or any information derived directly therefron, against the informant at a later trial. ${ }^{24}$ If the immunized witness is later brought to trial, the prosecution will have an obligation to show that the evidence used against the witness is derived from a legitimate source independent of the compelled testimony. ${ }^{25}$

\section{I}

\section{Habeas Corpus as a Civil Proceeding}

The writ of habeas corpus, sometimes referred to as the "Great Writ," is deeply rooted in Anglo-American jurisprudence and is considered "the most celebrated writ in the Enghish law."26 The Great Writ, whose history is "intertwined with the growth of fundainental rights of personal hiberty,"27 has traditionally provided "a prompt and efficacious remedy for whatever society deems to be intolerable restraints."28 Through this mechanism, a prisoner can collaterally attack his judgment and thereby question the legality of his restraint.

In Califorina, any person who is imprisoned under any pretense may prosecute a writ of habeas corpus to inquire into the legality of the imprisonment. ${ }^{29}$ One ground upon which a prisoner can base a petition for habeas rehief is that false evidence that was substantially material or

23. Kastigar v. United States, 406 U.S. 441, 461 (1972).

24. Id. at 453,460 . In Kastigar, the Supreme Court held that use immunity satisfies a witness' fifth annendment right to invoke his privilege against self-incrimination. Id. at 453, 462. Before Kastigar, only those statutes granting full "transactional inımunity" were upheld as constitutional. See, e.g., Ullman v. United States, 350 U.S. 422 (1956) (transactional immunity sufficiently protects fifth amendment rights of witness); Brown v. Walker, 161 U.S. 591 (1896) (same).

25. Kastigar, 406 U.S. at 460.

26. Fay v. Noia, 372 U.S. $391,399-400$ (1963) (quoting 3 BLACKSTONE, COMMENTARIES *129).

27. Id. at 401.

28. Id. at 401-02.

29. See Cal Penal Code $\S 1473(a)$ (West 1982). The California state prisoner's right to habeas corpus is also mandated by the California Constitution. See CAL. ConsT. art. $1, \S 11$ ("Habeas corpus may not be suspended unless required by public safety in cases of rebellion or invasion.").

It is important to recognize that there are two different types of habeas corpus relief-state and federal. Federal habeas corpus is guaranteed by the U.S. Constitution and the provisions of title 28 of the U.S. Code. See U.S. ConsT. art. I, § 9, cl.2; 28 U.S.C. $\S \S 2241-2256$ (1988). Federal habeas corpus is available to a person in custody pursuant to a judgment of a state court only when the applicant demonstrates that his imprisonnent violates the U.S. Constitution or some other federal law or treaty. See 28 U.S.C. § 2254(2) (1988). Illegality in the criminal trial that does not violate a federal constitutional right or federal law may not be attacked through an applieation for federal habeas corpus, even if the illegality is recognized by the state constitution or state laws. Even if a state-convicted prisoner does allege that a federal right has been violated, he may not apply for a federal writ of habeas corpus unless he has exhausted the postconviction remedies afforded by the courts of the state, or unless there is "either an absence of available State corrective process or the 
probative on the issue of guilt or punishment was introduced at a trial or hearing relating to his incarceration. ${ }^{30}$

In order to succeed on such a writ, the defendant need not allege nor prove that the prosecution knew or should have known that the evidence was false. ${ }^{31}$ To pursue this writ, the prisoner (or sonieone acting on his behalf) 1nust file a petition with the court that makes two showings. ${ }^{32}$ First, the petition must state with specificity facts sufficient to make a prima facie case that false evidence was introduced against hiın at trial. Next, the petition inust convince the reviewing judge that the false evidence introduced was substantially inaterial or probative on the issue of guilt or punishment. ${ }^{33}$

If the prisoner nuakes a prima facie case in the petition, the judge may then order an evidentiary hearing ${ }^{34}$ at which the prisoner nay allege and prove any facts estabhishmg that his imprisonment is unlawful or that he is otherwise entitled to discharge. ${ }^{35}$ The state also has an opportunity to present proof that the imprisonment is legal and should therefore be upheld. ${ }^{36}$ The judge has the power at this hearing to coinpel the attendance of witnesses, and to "do and perform all other acts and things necessary to a full and fair hearing and determination of the case."37

In assessing whether the allegedly false evidence was siguificant enough to have influenced the decision, the court will consider all the evidence and circumstances in the case, including other available evidence which might argue in favor of the conviction. ${ }^{38}$ Where the evidence in question was virtually the ouly evidence used against the

existence of circumstances rendering such process ineffective to protect the rights of the prisoner." 28 U.S.C. $\S 2254$ (b) (1988).

States, however, are not constitutionally compelled to provide habeas corpus relief for prisoners convicted under state law. See McKane v. Durston, 153 U.S. 684 (1894) (the Constitution does not require the states to grant appeals to defendants seeking review of trial court errors). States providing such relief do so either through state constitution or state legislation. Unless otherwise explicitly stated, this Comment addresses the prisoner's rights nnder the state habeas corpus proceedings provided for by California statute.

30. Cal. Penal Code $\S 1473(b)(1)$ (West 1982).

31. To qualify for relief prior to 1975 , a habeas corpus petitioner had to show that (1) the false testimony was perjured; and (2) the prosecution knew that the testimony was perjured. In $r e$ Wright, 78 Cal. App. 3d 788, 807, 144 Cal. Rptr. 535, 548 (1978). The 1975 amendment deleted both of these requirements. Wright, 78 Cal. App. 3d at 807-08, 809 n.5, 144 Cal Rptr. at 548, 549 n.5; Cal. Penal Code $\S 1473$ (West 1982).

32. Cal. Penal Code $\S 1474$ (West 1982).

33. Wright, 78 Cal. App. 3d at 807-09, 144 Cal. Rptr. at 548-49; Cal. Penal Code $\S 1473(\mathrm{~b})(1)$ (West 1982). This Comment will only address the first of these showings. The second showing - that the false testimony affected the outcome-differs depending on the particular facts of each case.

34. Cal. Penal Code $\S \S 1482-1484$ (West 1982).

35. Id. $\& 1484$.

36. Id.

37. Id.

38. In re Wright, 78 Cal. App. 3d 788, 144 Cal. Rptr. 535 (1978). 
defendant, the statute's test of materiahty will clearly be met. ${ }^{39}$

If the court determines that the petitioner has, in fact, been convicted on the basis of false evidence, and this evidence was substantially material or probative of guilt, the writ will issue and the prisoner will be granted a new trial. ${ }^{40}$

Although a writ of habeas corpus is granted to mquire imto the legality of a criminal conviction, it is not part of the criminal prosecution. Rather, the writ is an imdependent action mstituted by an applicant claiming that his imprisonment is tle result of an illegally obtained conviction. ${ }^{41}$ Many courts and commentators have referred to habeas proceedings as civil proceedings. ${ }^{42}$ As the Supreme Court stated in Ex parte Tom Tong : 43

The writ of habeas corpus is the remedy which the law gives for the enforcement of the civil right of personal hberty. Resort to it sometimes becomes necessary, because of what is done to enforce laws for the punishment of crimes, but the judicial proceeding under it is not to inquire into the criminal act which is complained of, but into the right to liberty notwithstanding the act. Proceedings to enforce civil rights are civil proceedings, and proceedings for the punishment of crimes are criminal proceedings. $^{44}$

Given that habeas proceedings are traditionally considered civil proceedimgs, they inay fit witlim the line of California precedent recognizing the residual power in certain situations to place restrictions on the use of

39. In re Hall, 30 Cal. 3d 408, 637 P.2d 690, 179 Cal. Rptr. 223 (1981). As discussed at supra note 10 , the prosecution may tend to use jailhouse informant testimony when the case against the defendant is weak. In many cases, therefore, the jailhouse informant testimony may have been the linchpin of the prosecution's case.

40. See In re Colford, 68 Cal. App. 308, 229 P. 63 (1924); In re Davis, 68 Cal. App. 801,229 P. 1114 (1924).

41. Ex parte Tom Tong, 108 U.S. 556, 559-60 (1883) (Supreme Court's jurisdiction could not be exercised in habeas corpus proceeding because of its civil nature); France v. Superior Court, 201 Cal. 122, 126-27, 255 P. 815, 817 (1927) (stating in dicta that the habeas corpus proceeding is not a proceeding within the criminal prosecution).

42. See, e.g., Browder v. Director, IIl. Dep't of Corrections, 434 U.S. 257, 269-70 (1978) (holding Federal Rules of Civil Procedure 52(b) and 59 applicable to habeas corpus proceedings and stating "[i]t is well settled that habeas corpus is a civil proceeding"); Fay v. Noia, 372 U.S. 391, 423 (1963) ("the traditional characterization of the writ of habeas corpus as an original . . civil reinedy for the enforcement of the right to personal liberty, rather than as a stage of the state criminal proceedings or as an appeal therefroin, einphasizes the independence of the federal habeas proceedings from what has gone before"); Ex parte Tom Tong, 108 U.S. 556, 559-60 (1883) (holding that writ of habeas corpus is a reinedy for the enforceinent of the civil right of personal liberty, and proceedings to enforce civil rights are civil proceedings); State v. Gordon, 105 Miss. 454, 62 So. 431 (1913) (holding that "[a] proceeding to enforce the right of personal liberty by means of a writ of habeas corpus is civil, and not criminal," so that a state may justify an appeal under statutes relating to civil cases); 39 AM. JuR. 2D Habeas Corpus $\S 10$ (1968). See generally Annotation, Right of State or Public Officer to Appeal from an Order in Habeas Corpus Releasing One from Custody, I0 A.L.R. 385, 401 (1921) (subsection (g): Habeas Corpus as 'civil' or 'crinninal' proceeding).

43. 108 U.S. 556 (1983).

44. Id. at $559-60$. 
statements in order to compel otherwise privileged testimony. ${ }^{45}$ The following Section examines this line of precedent and its rationale, and shows how it could easily and logically be apphed to the jailhouse informant situation.

\section{II}

\section{Judicial USE IMMUNITY AND STATUTORY COMPLIANCE}

This Section first examines the willingness of Californa courts to grant judicial use immunity in order to coinpel coinphance with a particular statute, where following the statute might otherwise violate the defendant's fifth amendment privilege against self-incrimination. This Section then argnes that judicial use immunity should be extended to jailhouse informants in order to coinpel these informants to testify in habeas corpus proceedings where the petitioner alleges that he was convicted on the basis of the informant's perjured testimony. This Section will show that a grant of judicial use immumity in such a case would not frustrate any legislative purpose behind the habeas statute but rather would further it. ${ }^{46}$

Finally, this Section will show that since a prosecutor in California niay lack the authority to grant immunity in habeas proceedings, judicial use immunity is the logical solution.

\section{A. The California Courts' Practice of Granting Use Immunity to Ensure Statutory Compliance}

Byers v. Justice Court, ${ }^{47}$ People v. Superior Court (Kaufman), ${ }^{48}$ and Gonzales v. Superior Court ${ }^{49}$ identify the situations in which a court may coinpel use immunity. These cases recognize that the legislature expects courts to further the socially desirable goals of the statutes enacted by the

45. See Government of Virgin Islands v. Smith, 615 F.2d 964, 969-70 (3d Cir. 1980); United States v. Herman, 589 F.2d 1191 (1978), cert. denied, 441 U.S. 913 (1979); Daly v. Superior Court, 19 Cal. 3d 132, 560 P.2d 1193, 137 Cal. Rptr. 14 (1977); People v. Superior Court (Kaufman), 12 Cal. 3d 421, 525 P.2d 716, 115 Cal. Rptr. 812 (1974); Byers v. Justice Court, 71 Cal. 2d 1039, 458 P.2d 465, 80 Cal. Rptr. 553 (1969), rev'd on other grounds sub nom. California v. Byers, 402 U.S. 424 (1971).

46. Of course, there are other important state interests at stake, such as deterring witnesses from lying on the stand. See CAL. PENAL CODE $\S 118$ (West Supp. 1990). See infra text accompanying notes 158-73 for a discussion of how a court should balance the defendant's interest in challenging the outcome of a trial in which a jailhouse informant has testified with the state's interest in a perjury conviction.

47. 71 Cal. 2d 1039, 458 P.2d 465, 80 Cal. Rptr. 553 (1969), rev'd on other grounds sub. nom. California v. Byers, 402 U.S. 424 (1971). For a description of the facts of this noteworthy case, see infra text accoinpanying notes 51-70.

48. 12 Cal. 3d 421, 428-29, 525 P.2d 716, 720-21, 115 Cal. Rptr. 812, 816-17 (1974) (compelled testimony in civil suit for false advertising cannot be used in criminal prosecution).

49. $117 \mathrm{Cal}$. App. 3d 57, 70-72, $178 \mathrm{Cal}$. Rptr. 358, 365-66 (1980) (use immunity granted by court in civil child support case even absent express statutory authority). 
legislature. The courts cannot, however, infringe on a person's fifth amendment rights in order to further the legislative intent behind a statute. The courts have therefore developed a test that attempts to proinote the social good intended by a statute without compromising the witness' right not to incriminate himself. Under this two-part test, the court will not immunize statements unless: (1) the statements further the legislative purpose of a civil statute, and (2) the immunity does not "unduly hamper" future criminal prosecutions. ${ }^{\text {so }}$

In Byers v. Justice Court, ${ }^{51}$ the California Suprene Court first recognized the validity of judicially imposed use immunity as a device to reconcile private interests with the government's interest in obtaining certain inforniation. ${ }^{52}$ Following the lead of the United States Supreine Court, ${ }^{53}$ Byers held that a court could impose restrictions on the use of incriminating evidence coinpelled by a vehicle code statute despite the absence of an exphicit statutory authorization for a grant of immumity under such circumstances. ${ }^{54}$

In Byers, Jonathan Byers was charged with two violations of the vehicle code. Count One charged him with unsafe and improper passing in violation of California Vehicle Code section 21750. Count Two charged him with violating the "hit-and-run" provisions of Vehicle Code section 20002(a), which make it a crime for a driver to leave the scene of an autonobile accident that results in property dainage, without announcimg his identity and certain other infornation to the owner of the damaged property. ${ }^{55}$ Byers claimed that section 20002 was unconstitutional as applied because it required him to provide self-incriminating inforniation. $^{56}$

The court recognized two competing interests: Byers' interest in

50. Byers, $71 \mathrm{Cal} .2 \mathrm{~d}$ at 1056, 458 P.2d at 477, 80 Cal. Rptr. at 565; Kaufman, 12 Cal. 3d at 428-29, 525 P.2d at 721, $115 \mathrm{Cal}$. Rptr. at 817 . Hereafter I will refer to this two-part analysis as the Byers/Kaufman doctrine.

51. 71 Cal. 2d 1039, 458 P.2d 465, 80 Cal. Rptr. 553 (1969), rev'd on other grounds sub nom. California v. Byers, 402 U.S. 424 (1971).

52. As explained at supra note 14 , use immunity prevents the state from using compelled testimony, or the frnits thereof, in connection with a criminal proceeding against the witness. Use immunity does not, however, completely bar the state from prosecuting the witness. Rather, any evidence used against the witness in his criminal prosecution must be "untainted" by any information he divulged while immunized. Byers, $71 \mathrm{Cal}$. 2d at 1051-52, 458 P.2d at 473-74, 80 Cal. Rptr. at 561-62; see also Kastigar v. United States, 406 U.S. 441, 453 (1972) (use inmurity satisfies the witness' fifth amendment privilege not to incriminate himself).

53. See Marchetti v. Umited States, 390 U.S. 39, 58-60 (1968) (after finding tax disclosure law violated fifth amendment, court considered imposing use iminunity under judiciary's inherent powers but concluded that such immumity would frustrate purpose of statute); Murphy v. Waterfront Comm'n, 378 U.S. 52, 79 (1964) (use inmunity granted by state prosecutors under state lav also prevents federal prosecutors from using testimony to charge witness with federal crimes).

54. Byers, $71 \mathrm{Cal} .2 \mathrm{~d}$ at $1057,458 \mathrm{P} .2 \mathrm{~d}$ at $477,80 \mathrm{Cal}$. Rptr. at 565.

55. Id. at $1041-42,458 \mathrm{P} .2 \mathrm{~d}$ at $467,80 \mathrm{Cal}$. Rptr. at 555 .

56. Id. at 1042,458 P.2d at 467,80 Cal. Rptr. at 555 . 
preserving his fifth amendment right not to incriminate himself, and the government's imterest in ensuring comphance with the statute. ${ }^{57}$ To reconcile these two interests, the court prohibited the information disclosed pursuant to the statute from being used in criminal prosecutions related to the accident. ${ }^{58}$ In other words, the court protected the statements by a judicial grant of use immunity. ${ }^{59}$

The court stated two grounds for this immunity: First, the use restriction would not frustrate any important legislative purpose behind the hit-and-run statute. ${ }^{60}$ Second, the restrictions would not "unduly hamper" the criminal prosecution of drivers involved in hit-and-run accidents. ${ }^{61}$

In determining that the restrictions would not frustrate a significant legislative purpose, the court conducted a two-part analysis. First, the court looked at the face of the statute to see whether it disclosed any legislative intent "to facilitate prosecutions for possible criminal acts occurring in connection with automobile accidents."62 Finding no such intent on the face of the statute, the court then examined the basic purpose of the statute. ${ }^{63}$ The court found that the legislature enacted the hit-and-run statute prinarily to protect the interests of the private parties whose property is damaged, not to facilitate the criminal prosecution of the errant driver. ${ }^{64}$ The court then concluded:

Imposing use-restrictions in the present case merely involves this court in making a judgment, based on the assessment of probable legislative intent, that the Legislature would prefer to have the provisions of section 20002 of the Vehicle Code upheld even in cases involving possible criminal misconduct at the cost of some burden on prosecuting authorities in criminal cases arising out of or related to an accident covered by that section rather than avoid that burden at the cost of significantly frustrating the important noncriminal objective of the legislation. ${ }^{65}$

In essence, the court found that the statute imphicitly authorized the grant of immunity because without such a grant the disclosure requirement would be rendered ineffective. ${ }^{66}$

The court noted, however, that its inposition of use innnunity in this case would not preclude the legislature from enacting legislation

57. Id. at 1049,458 P.2d at $472,80 \mathrm{Cal}$. Rptr. at 560 .

58. Id. at 1056-57, 458 P.2d at $477,80 \mathrm{Cal}$. Rptr. at 565 .

59. Id., 458 P. $2 \mathrm{~d}$ at $477,80 \mathrm{Cal}$. Rptr. at 565 .

60. Id. at 1054-55, 458 P.2d at 475-76, 80 Cal. Rptr. at 563-64.

61. Id. at $1056,458 \mathrm{P} .2 \mathrm{~d}$ at $476-77,80 \mathrm{Cal}$. Rptr. at 563 .

62. Id. at $1054,458 \mathrm{P} .2 \mathrm{~d}$ at $475,80 \mathrm{Cal}$. Rptr. at 563 .

63. Id., 458 P.2d at 475,80 Cal. Rptr. at 563 .

64. Id. at 1054-55, 458 P.2d at 475-76, 80 Cal. Rptr. at 563-64.

65. Id. at 1055, $458 \mathrm{P} .2 \mathrm{~d}$ at $476,80 \mathrm{Cal}$. Rptr. at 564 .

66. See People v. Superior Court (Kaufman), 12 Cal. 3d 421, 427-28, 525 P.2d 716, 720, 115 Cal. Rptr. 812, 816 (1974) (analyzing the Byers opinion). 
declaring that information derived from compliance with the hit-and-run statute could be used in criminal prosecutions. ${ }^{67}$ Thus, the court recognized the legislature's ability to override the judicial decision.

In analyzing the second question-whether use restrictions would unduly hamper criminal prosecutions of drivers mvolved in accidentsthe court compared the number of those criminal violations on the lighway with the number of violations involving property damage. ${ }^{68}$ According to the court, a vast number of highway violations do not involve property danage. ${ }^{69}$ Since use immumity would only burden the prosecution of that class of cases involving property damage, such a grant of use immunity would not "unduly hamper" criminal prosecutions within the ineaning of the two-part test. ${ }^{70}$

In People v. Superior Court (Kaufman), ${ }^{71}$ the California Suprenie Court reaffirmed a court's ability to impose use immunity despite the absence of legislative authorization. In Kaufman, the court followed the trend set by Byers and hiberally construed a civil statute so as to protect an alleged wrongdoer from later criminal prosecution. ${ }^{72}$ In so doing, the court inandated the issuance of a protective order in a civil proceeding to limit the use of a deposition in any criminal proceedimg which might thereafter be instituted against the deponent. ${ }^{73}$

In Kaufman, the state commenced civil proceedings against inultiple defeudants, alleging that the defendants fraudulently misled niembers of the public into beheving that the defendants' services could lead to einploynent in the advertising, modeling, or entertainment fields. ${ }^{74}$ The state deposed one defendant, Kaufman, during the pretrial proceedings. ${ }^{75}$ Although Kaufman answered certain background questions, he refused to answer any questions that would connect him to allegedly fraudulent activities. Kaufnian feared that his responses to such questions could lead to the production of evidence that might intplicate him in criminal conduct. ${ }^{76}$

The court granted the protective order, holding that the order would not frustrate-but indeed would further-the legislative purpose of suppressing deceptive advertising. ${ }^{77}$ In addition, the court believed that such an order would not unduly hamper the prosecution of persons

67. Byers, 71 Cal. 2d at 1055, 458 P.2d at 476,80 Cal. Rptr. at 564 .

68. Id. at 1056, 458 P.2d at $476-77,80$ Cal. Rptr. at 564-65.

69. Id., 458 P. $2 \mathrm{~d}$ at $476-77,80 \mathrm{Cal}$. Rptr. at 564 .

70. Id., 458 P. $2 \mathrm{~d}$ at $476-77,80 \mathrm{Cal}$. Rptr. at 564-65.

71. 12 Cal. 3d 421, 525 P.2d 716, 115 Cal. Rptr. 812 (1974).

72. Id. at $427,525 \mathrm{P} .2 \mathrm{~d}$ at $720,115 \mathrm{Cal}$. Rptr. at 816.

73. Id. at $428-29,525$ P.2d at 721,115 Cal. Rptr. at 817 .

74. Id. at $424 \mathrm{n} .1,525 \mathrm{P} .2 \mathrm{~d}$ at $718 \mathrm{n} .1,115 \mathrm{Cal}$. Rptr. at 814 n.1.

75. Id. at $424,525 \mathrm{P} .2 \mathrm{~d}$ at $718,115 \mathrm{Cal}$. Rptr at 814 .

76. Id. at $424-25,525 \mathrm{P} .2 \mathrm{~d}$ at $718,115 \mathrm{Cal}$. Rptr. at 814 .

77. Id. at $428-29,525 \mathrm{P} .2 \mathrm{~d}$ at $721,115 \mathrm{Cal}$. Rptr. at 817 . 
who, in the judgment of the authorities, should be the subject of criminal proceedings. ${ }^{78}$ Finally, the court again recognized the legislature's ability to statutorily redefine the limits of judicial use immunity if the court's grant did not conform to legislative intent. ${ }^{79}$

The Califorma Court of Appeals had an opportunity to apply the Byers/Kaufman doctrime in Gonzales v. Superior Court. ${ }^{80}$ In Gonzales, the district attorney brought three civil actions pursuant to Welfare \& Institutions Code section 11350, on behalf of certain ninor children and their mothers, to estabhsh the patermity of the children and obtain support payments from the alleged fathers. ${ }^{81}$ Section 11350 inandates such an action whenever a mother or child is a recipient of Aid to Families with Dependent Children (AFDC) and a noncustodial parent is involved. Pursuant to this suit, the alleged fathers were asked to answer certain written interrogatories regarding their financial condition and sexual relationships with the respective mothers. The men involved, each of whon denied patermity, refused to answer the interrogatories, claiming the privilege against self-incrimination. ${ }^{82}$ According to the alleged fathers, the answers to the interrogatories might have exposed then to prosecution for failure to pay child support under Penal Code section $270 .{ }^{83}$

The court first noted that judicial use innuunity "purports to relieve an alleged wrongdoer of the threat of criminal prosecution in exchange for incriminating information which the legislature has deened to serve some socially desirable policy." ${ }^{84}$ It went on to analyze the intent behind

78. Id. at 429,525 P.2d at $721,115 \mathrm{Cal}$. Rptr. at 817 . The court did not give its reasons for holding that the protective order in this case would not unduly hamper crininal prosecutions.

79. Id., 525 P.2d at $721,115 \mathrm{Cal}$. Rptr. at 817. In Kaufman, the source of the court's authority to compel use immunity through a protective order was section 2019 of the Code of Civil Procedure rather than the implicit authorization of the violated statute (as in Byers). Section 2019 relates to oral depositions and provides for "numerous court orders designed to facilitate the disclosure of information, to minimize intrusion into private areas, and to maintain security of such disclosures." Id. at 425, 525 P.2d at 718, $115 \mathrm{Cal}$. Rptr. at 814.

80. 117 Cal. App. 3d 57, 178 Cal. Rptr. 358 (1980). The California Supreme Court had addressed the applicability of the doctrine three years before Gonzales in Daly v. Superior Court, 19 Cal. 3d 132, 560 P.2d 1193, 137 Cal. Rptr. 14 (1977). Daly involved a wrongful dcath suit and other tort actious solely between private parties. Several of the defendants refused to answer deposition questions on the grounds of self-incrimination. Because no representative of the People was beforc the court to object to the grant of use immumity, the court found that granting use immunity without taking steps to prevent undue interference with prosecutorial discretion might "unduly hamper" subsequent crimmal prosecutions. Id. at 138, 560 P.2d at 1197, $137 \mathrm{Cal}$. Rptr. at 18. The court therefore held that it would grant a protective order only if the parties notified the affected prosecuting agency of the request, and the prosecuting agency failed to object to the issuance of the order. Id. at 146-48, 560 P.2d at 1202-03, 137 Cal. Rptr. at 24-25.

81. Gonzales, 117 Cal. App. $3 \mathrm{~d}$ at 59-60, $178 \mathrm{Cal}$. Rptr. at 359.

82. Id. at $60-61,178 \mathrm{Cal}$. Rptr. at 359.

83. Id. at 60 n.2, $178 \mathrm{Cal}$. Rptr. at 359 n.2.

84. Id. at $69,178 \mathrm{Cal}$. Rptr. at 364 . 
section 11350, which requires that the absent, noncustodial parent reimburse the county for the AFDC payments made to support that person's child. Many of the mothers who apply for AFDC, explained the court, are unsure of the identity of the fathers or about the fathers' ability to pay. As a result, the interrogatories are essential to develop the evidence necessary to bring the complaints to judgment. Because of the necessity of such information, the court found that every effort should be made and all available devices employed to facilitate the purposes of section 11350 , and stated that this situation "cr[ied] out for [the] apphication of the rule aimounced in Kaufman."85 In order to further the purposes of section 11350, the court held that the information sought was discoverable provided that the alleged fathers were given use immunity. ${ }^{86}$

\section{B. Extension of Judicial Use Immunity to Informant-Perjurers}

The judicial use immunity apphied in the cases above should likewise be granted in an evidentiary hearing on a writ of habeas corpus in the jailhouse informant context. Such grants would further the purpose of the habeas corpus statute by compelling jailhouse informants to testify regarding any perjured statements made at trial. Prosecuting a recantmg informant for perjury, on the other hand, would frustrate the purpose of the habeas statute by preventing the witness from testifying and thus restricting the defendant's ability to present exculpatory evidence necessary to support the writ. ${ }^{87}$

\section{The Legislative Purpose of Habeas Corpus as Consistent with Judicial Use Immunity}

Our criminal justice system is based on the notion that one cannot be imprisoned without a fair trial. ${ }^{88}$ The Califorria legislature has enacted statutory provisions for prosecuting a writ of habeas corpus in order to guarantee this imvaluable right. ${ }^{89}$ Implicit in this notion is that it is in society's best interest to provide a remedy in those situations where false evidence and/or testimony has been offered at trial. Society

85. Id. at 71-72, $178 \mathrm{Cal}$. Rptr. at 366 .

86. Id. at 70-72, $178 \mathrm{Cal}$. Rptr. at 365-66. It is important to note that the district attorney did not request use immunity. Rather, the state sought an order to compel answers to interrogatories. Id. at 60-61, $178 \mathrm{Cal}$. Rptr. at 359-60. The court, however, relying on the authority of Kaufman, ordered a grant of use immumity in order to reconcile the state's urgent need for the information with the alleged fathers' fifth amendment right. Id. at 70-72, $178 \mathrm{Cal}$. Rptr. at 359-60.

87. For a discussion of the constitutional implications of preventing a defendant from introducing exculpatory evidence, see infra notes $158-66$ and accompanying text.

88. See U.S. CONST. amend. V ("No person shall be ... deprived of life, hberty, or property, without due process of law . ..."); U.S. Consr. amend. VI (providing for the right to a fair and speedy trial, confrontation of witnesses, compulsory process, and assistance of counsel).

89. See Cal. Penal Code $\S 1473$ (West 1982). The text of section 1473 is partially reproduced at supra note 8 . 
must strive to uncover deceit in the criminal justice process, or the right to a fair trial is meaningless.

In essence, the function of a writ of habeas corpus available under section 1473 of the California Penal Code is to mquire into the legality of the process by which a person was imprisoned. ${ }^{90}$ Granting use immunity to jailhouse informants who perjure themselves at trial does not frustrate this purpose-it furthers it. Although there are nornally several ways to prove that false evidence was used against a defendant at trial, perjury is difficult to prove, especially when ouly the perjurer and the defendant know the truth. ${ }^{91}$ A grant of judicial use immunity to the informant at an evidentiary hearing inay be the only way for the defendant to prove that he was convicted on the basis of false testimony. Without such a mechamism, the writ of habeas corpus cannot reinedy the illegal imprisonment.

\section{The Effect of Granting Judicial Use Immunity to Jailhouse Informant-Perjurers on Subsequent Perjury Prosecutions}

The second mquiry under the Byers/Kaufman doctrine is whether judicial use immunity will "unduly hamper" criminal prosecutions..$^{92} \mathrm{~A}$ prosecution is hampered when a certain action decreases the state's reasonable expectation of a conviction. In the jailhouse informant scenario, the state needs the informant's testimony at the habeas proceedings in order to support a perjury charge. Unless the state grants inmumity to the jailhouse informant, however, the informant will probably invoke his privilege against self-incrimination when questioned about his prior testimony. Indeed, although certain inforniants have admitted to committing

90. See In re Drake, 38 Cal. 2d 195, 197, 238 P.2d 566, 568 (1951) (purpose of writ of habeas corpus is to test legality of imprisonment); In re Jacinto, 8 Cal. App. 2d 275, 276, 47 P.2d 300, 300 (1935) (purpose of writ is to test legality of process of imprisonment).

91. In the typical jailhouse informant case, the informant-perjurer testifies that he was privy to a defendant's confession when in fact the defendant never confessed. Because the informant fabricated the confession, he is likely to be the only person who can reveal the truth. Even if the informant admits his perjury to another inmate, it is against the second inmate's interest to reveal this fact. If, for example, he is involved as a "snitch" in another case, he would not want to undermine the legitunacy of informant information generally. Even if he is not an informant, he may fear that if he informs on his fellow inmate-imformant he may suffer physical abuse by other inmates.

92. Neither Kaufman nor Gonzalez explicitly addressed this issue. The second part of the test is derived from Byers v. Justice Court, 71 Cal. 2d 1039, 1056, 458 P.2d 465, 476-77, 80 Cal. Rptr. 553, 564-65 (1969), rev'd on other grounds sub nom. California v. Byers, 402 U.S. 424 (1971). For a discussion of the application of the test, see supra text accompanying notes 68-70. Although the court also considered this part of the test in Daly v. Superior Court, 19 Cal. 3d 132, 145-46, 560 P.2d 1193, 1201-02, 137 Cal. Rptr. 14, 22-23 (1977), it did so in the context of private party civil litigation. Because the state will necessarily be a party to any habeas proceedings, Daly should not be determinative here. 
perjury on at least ten occasions, ${ }^{93}$ they refuse to identify particular mstances where they made perjured statements without an immunity grant. ${ }^{94}$ Because of this circular dynamic, the state is in substantially the same evidentiary predicament if use immunity is granted as it would have been in if the informant had mvoked his privilege. ${ }^{95}$

Because a grant of immunity to a jailhouse informant would further the legislative intent of Califorma Penal Code section 1473 without unduly hampering later criminal prosecutions, the court should use its authority to grant such immunity.

\section{Differences Between the Settled Case Law and the Jailhouse Informant Situation}

Although habeas proceedings seem to fit within the framework discussed above, there are some notable differences between the cases discussed and the jailhouse informant situation. Although the differences do not seriously undermine the viability of the argument, they do deserve mention.

The first difference is the type of disclosure sought in the proceeding. The statutes above require a specific, statutorily delineated disclosure. As a result, the judge knows the exact nature of the information that will be disclosed and thus can estimate the confines of any immunity grant. In the jailhouse informant situation, the information sought is not as clearly defined. Although the prisoner is merely requestimg that the informant confess to having perjured himself at trial, there is no telling what the informant might actually say once he takes the stand at an evidentiary hearing. While a grant of judicial use immunity will not prevent the prosecution of any crime to which the witness might admit, it will prevent the use of the testimony, or any fruits gamed therefrom, against the informant if he is later tried for a substantive crime. Thus, a judge may be more wary of granting immunity in this situation, where the scope of the testimony is not clearly delineated, than she imght be in the cases cited above.

A second issue is raised by the fact that in each of the cited cases the state, through its statute, has compelled the disclosure of certam information. Thus, the individual was forced to comply with a civil statute so as to possibly mcriminate himself. In each case, if the court did not grant

93. See, e.g., Rohrlich, Jail Inmate Says He Lied in Role as Informant, L.A. Times, Dec. 1, 1988, pt. II, at 1, col. 1.

94. See supra note 11 and accompanying text.

95. Cf. Kastigar v. United States, 406 U.S. 441, 458-59 \& n. 48 (1972) ("[I]mmunity from use and derivative use "leaves the witness and the Federal Government in substantially the same position as if the witness liad claimed his privilege' in the absence of a grant of immunity." (footnote omitted) (quoting Murpliy v. Waterfront Comm'n, 378 U.S. 52, 79 (1964))). 
immunity, it would have to either permit the defendant to invoke his fifth amendment privilege and refuse to testify, or declare the statute unconstitutional.

In the jailhouse informant situation, however, there is no state action compelling the testimony of the jailhouse informant witness. In fact, it is the prisoner who is seeking to compel the testimony. It is true that the state has generally expressed its intent that an illegally imprisoned defendant have the ability to present evidence that false testimony was introduced agamst him at trial. It is also true that the only way to ensure that the defendant will have this ability is to compel the testimony of the informant. However, it is stretching the logic to argue that the state, through the habeas statute, has compelled an informant to testify.

In spite of these conceptual differences, the Cahifornia cases do authorize judicial use immunity $\mathrm{m}$ a civil context. These cases also recognize that the legislative intent of a statute should be effectuated if the court is able to do so. Since a grant of immunity to a jailhouse informant would further the legislative intent of Cahiforma Penal Code section 1473 without unduly hamperimg later criminal prosecutions, the court should use its authority to grant such immunity.

\section{The Prosecution Does Not Have Authority to Grant Immunity in Civil Proceedings}

The argument in favor of judicial use immunity in habeas corpus proceedings is strengthened by the fact that the state niay lack the statutory authority to grant immunity in this context. The prosecution's authority to immunize a witness derives from California Penal Code section $1324 .{ }^{96}$ Section 1324 allows the court, at the request of the district attorney, to grant transactional immumity to a witness who asserts his fifth amendment privilege. ${ }^{97}$ The district attorney, however, only has the

\footnotetext{
96. Section 1324 provides:

In any felony proceeding or in any investigation or proceeding before a grand jury for any felony offense if a person refuses to answer a question or produce evidence of any other kind on the ground that he may be incriminated thereby, and if the district attorney of the county in writing requests the superior court ... to order that person to answer the question or produce the evidence ... and the court shall order the question answered or the evidence produced unless it finds that to do so would be clearly contrary to the public interest, or could subject the witness to a criminal prosecution in another jurisdiction, and that person shall comply with the order. After complying, and if, but for this section, he would have been privileged to withhold the answer given or the evidence produced by him, that person shall not be prosecuted or subjected to penalty or forfeiture for or on account of any fact or act concerning which . . . he was required to answer or produce evidence. But he may nevertheless be prosecuted ... f for any perjury, false swearing or contempt committed in answering, or failing to answer, or in producing, or failing to produce, evidence in accordance with the order.
}

Cal. Penal Code $§ 1324$ (West 1982) (emphasis added).

97. Id. For a comparison of transactional and use imınunity, see supra note 14. 
power to request immunity in a "felony proceeding or in any investigation or proceeding before a grand jury for any felony offense."98

Because a habeas proceeding is not a part of the felony proceeding, the district attorney is not authorized under section 1324 to request immunity. ${ }^{99}$ Thus, there is a coinpelling argument that the court must be able to grant immunity. First, by granting use immunity in a habeas proceedinig, the court would not be preempting an area traditionally left to prosecutorial discretion. ${ }^{100}$ Second, because the court has the statutory authority within habeas proceedings to "do and perform all . . . acts and things necessary to a full and fair hearing and determination of the case," 101 the court seeins to have the statutory authority to grant use immunity in this context. ${ }^{102}$

98. Cal. Penal Code $\S 1324$ (West 1982).

99. In re Weber, 11 Cal. 3d 703, 719-20, 523 P.2d 229, 239-40, 114 Cal. Rptr. 429, 439-40 (1974) (Attorney General properly refused to request immunity at an evidentiary hearing on a writ of habeas corpus because such a proceeding is not within the reach of Penal Code section 1324); see also 20 CAL. JUR. 3D Criminal Law $\$ 2293$ n.54 (1985). One could argue that habeas corpus proceedings, as "special proceedings of a criminal nature," fall withm section 1324 , but that analysis is beyond the scope of this Comment.

Even if a court finds that a habeas proceeding is within the prosecutor's authority under section 1324, there are alternative avenues that a defendant may pursue in order to have a jailhouse informant iminunized without a request from the prosecution. Due process may require the state itseif to request use immunity for a defendant's witness where prosecutorial misconduct has created the need for the inninumity grant. See Uinited States v. Patterson, 819 F.2d 1495, 1506 (9th Cir. 1987) ("If it can be shown that the prosecution intentionally distorted the fact-finding process ... then due process requires aequittal unless immunity is granted.") (emphasis in original); Umited States v. Morrison, 535 F.2d 223, 229 (3d Cir. 1976) (prosecutorial misconduct causing the defeuse witness to withhold testimony violated the defendant's due process rights, and the prosecution was required to request immumity for the witness at trial); In re Martin, 44 Cal. 3d 1, 744 P.2d 374, 241 Cal. Rptr. 263 (1987) (prosecutorial misconduct resulting im the intimidation of witnesses such that they refused to testify for fear of self-incrimination violated defendant's compulsory process rights). Thus, where the court finds that prosecutorial misconduct has contributed to the need for the immunity grant, the court may put the state to a choice: either grant immunity to the witness or disiniss the case. Id.

Similarly, evidence that the District Attorney's office was aware of the unreliability of certain jailhouse informants and yet continued to use their testimony in otherwise weak cases might compel the court to give the state a comparable choice: either grant the informant use immunity or grant the defendant a new trial in which the informant is precluded from testifying. See Cody, Jailhouse Informants: The D.A.'s Ethical Bind, L.A. Times, Nov. 13, 1988, pt. III, at 3, col. 1 (statement of Richard G. Hirsh, former president of Califorma Attorneys for Criminal Justice) ("The district attorney's office calls jailhouse informants as witnesses in almost every murder case it prosecutes where the case appears weak."); Rohrlich, Jail Inmate Says He Lied in Role as Informant, L.A. Times, Dec. 1, 1988, pt. II, at 1, col. 1 ("Despite his reputation as a har, White continued to be used as a prospective prosecution witness until late October, when he denionstrated for sheriffs deputies how casily he could fake another immate's confession.").

100. For a full discussion of the issue of separation of powers in the immunity context, see infra note 141 and accoinpanying text.

101. Cal. Penal Code $\S 1484$ (West 1982).

102. Even if the prosecutor had the power to grant immunity within a habeas proceeding, a judicial grant would be preferable. As previously stated, the state's power to inımunize a witness is delineated by statute. See CAL. Penal CoDE $\S 1324$ (West 1982). Under the statute, the state niay 
The arguinent in favor of judicial use immunity in habeas proceedings is bolstered further by the considerable leeway courts have in conducting habeas corpus proceedings. In hight of the broad remedial purpose of habeas corpus, it has traditionally been regarded as a proceeding in which a "liberal judicial attitude is peculiarly appropriate." 103 This notion is reflected in the statutory language cited above, which gives the court the broad power to do anything necessary to foster a full and fair hearing of the defendant's claim. ${ }^{104}$

\section{III \\ Judicial USE IMMUNITY AS CONSTITUTIONALLY COMPELLED}

In addition to the civil precedent for judicial grants of use iminunity, both Califorina and federal case law support such immumity where necessary to protect the defendant's constitutional right to a fair trial. This Section argues, first, that a defendant in a criminal trial has a due process and compulsory process right to present the testimony of an exculpatory witness unless the state has a strong countervailing interest in preventing such testimony. Several courts have applied this principle to justify grants of judicial use immunity to defense witnesses in criminal trials. Next, this Section shows that a prisoner retains the same constitutional rights within a postconviction proceeding that he had at trial. Finally, it argues that in a habeas corpus proceeding, where the petitioner asserts that a jailhouse inforinant perjured himself at trial, the defendant's interest in presenting exculpatory evidence invariably outweighs the state's interest in preventing the immunization of jailhouse informants.

\section{A. The Defendant's Constitutional Due Process Right to Present Exculpatory Evidence}

The Supreme Court has never directly addressed the question of

only grant transactional immunity. The court, however, is not limited by any statutory grant of power. Thus, the court may grant use immunity. The Supreme Court has stated that use ininunity adequately protects the defendant's fifth amendment right not to incrininate hiniself, and therefore compellimg the witness to testify under such a grant would not violate the witness' constitutional rights. See Kastigar v. United States, 406 U.S. 441 (1971).

A grant of use immunity would actually better serve the state's interest than a grant of transactional immunity, since use immunity wonld not preclude later prosecution of the witness for any substantive crime for which he may implicate himself. Use immunity would nerely prevent the state from using this testimony, or the fruits gained therefrom, in a later crininal proceeding.

103. Stewart v. Overholser, 186 F.2d 339, 342 (D.C. Cir. 1950) (quoting Mercado v. United States, 183 F.2d 486, 487 (1st Cir. 1950)).

104. Cal. Penal Code $\S 1484$ (West 1982). 
whether a defendant has a constitutional right to have a witness immunized where that witness will otherwise refuse to testify on fifth amendnient grounds. The Court has, however, held that the due process clause forbids the state from arbitrarily denying relevant, material, or exculpatory evidence to the defendant $\dot{\mathrm{n}}$ a criminal prosecution.

In Chambers $v$. Mississippi, ${ }^{105}$ a common law rule prohibited a party from impeaching his own witness, thus preventing the defendant (Chambers) from cross-examining a key witness. ${ }^{106}$ The state's hearsay rules, which limited the introduction of declarations agamst penal interest, also prevented Chambers from imtroducing other informal admissions of the witness' guilt which would have exculpated lim1. ${ }^{107}$

The Supreme Court held that Mississippi's strict adherence to these rules of evidence effectively denied the defendant a fair trial in accordance with the principles of due process because they prevented limi from nitroducing trustworthy exculpatory evidence. ${ }^{108}$ Noting that few rights are more fundamental than that of an accused to present witnesses in his own defense, the Court refused to let Mississippi's rules of evidence "be apphied mechanistically to defeat the ends of justice," and reversed Chambers' conviction. ${ }^{109}$

The Supreme Court recognized similar rights in Brady $v$. Maryland ${ }^{110}$ and Roviaro v. United States. ${ }^{111}$.In Brady, the Court held that a defendant was deprived of his due process right to a fair trial where the prosecution suppressed evidence niaterial to the accused's defense. ${ }^{112}$ In Rovario, the Court held that due process requires the government to disclose an informant's identity where that information would facilitate the truth-seeking process. ${ }^{113}$

In each of these cases, the Court balanced the state's niterests in withholding the infornation agaimst the defendant's interest $\mathrm{n} 1 \mathrm{a}$ fair trial. In Chambers, the Court reconsidered the purposes behind the comnion law "voucher rule" in light of its likely detrimental effect on the defendant's ability to present a forceful case. ${ }^{114}$ The Court held that strict adherence to the evidence rules could deprive the defendant of his right to a fair trial in certain circumstances. Likewise, in Rovario the Court balanced the government's need to preserve the confidentiality of

105. 410 U.S. 284 (1973).

106. Id. at 295.

107. Id. at 298-99.

108. Id. at 302 .

109. Id.

110. 373 U.S. 83 (1963).

111. 353 U.S. 53 (1957).

112. Brady, 373 U.S. at 87. The state failed to disclose, upon request, an out-of-court coufession of a codefendant that would have exonerated the defendant. Id. at 84.

113. Roviaro, 353 U.S. at 60-61.

114. Chambers, 410 U.S. at $296-98$. 
its informants against the defendant's need to present a defense. The Court concluded: "[W] here the disclosure of an informer's identity, or of the contents of his communication, is relevant and helpful to the defense of an accused, or is essential to a fair determination of a cause, the privilege inust give way." 115 Similarly, in Brady the Court found that there was no legitimate state interest in withholding potentially exculpatory evidence from the defendant. ${ }^{116}$ These cases demonstrate the Court's willingness to invoke the broad proscriptions of due process in order to protect a defendant's right to present exculpatory evidence.

\section{B. The Defendant's Sixth Amendment Right to Compulsory Process}

In addition to the general right to a fair trial guaranteed by the due process clause, the Supreine Court has used the sixth amendment right to coinpulsory process to support a defendant's right to present a defense. ${ }^{117}$ The right to compulsory process enables a defendant to subpoena and present witnesses at trial, and to present evidence on his own behalf in order to support his version of the facts. ${ }^{118}$ Certain coinunentators refer to the coinpulsory process right as the "defendant's affirmative personal right to present testimony in his favor." 119

In Washington v. Texas, ${ }^{120}$ the Supreine Court held that the defendant was denied his coinpulsory process rights when the state arbitrarily refused to allow the testimony of a witness who was physically and inentally capable of testifying and whose testimony was relevant and material to the defense. ${ }^{121}$ Washington was convicted of inurder with inalice and sentenced to fifty years in prison. ${ }^{122}$ At trial, the prosecution introduced evidence showing that Washington and several other youths, motivated by jealousy, had driven to Washington's ex-girlfriend's house with a shotgun. The woman's new boyfriend was fatally shot in an ensuing fight. ${ }^{123}$ It was uncertain whether Washington or another man, Fuller, had actually done the shooting. Fuller was willing to testify that Washington had

115. Roviaro, 353 U.S. at $60-61$ (footnote omitted).

116. Brady, 373 U.S. at 87-88.

117. U.S. CONST. amend. VI ("In all criminal prosecutions, the accused shall enjoy the right ... to have compulsory process for obtaining witnesses in his favor."). The sixth amendment right to compulsory process is applicable to the states through the fourteenth amendment. See Washington v. Texas, 388 U.S. 14,18 (1967).

118. A defendant's sixth amendment right to secure the attendance of a witness does not override a witness' right to invoke his fifth amendment privilege not to testify. See United States v. Paris, 827 F.2d 395, 399 (9th Cir. 1987); United States v. Taylor, 728 F.2d 930, 934 (7th Cir. 1984).

119. Comment, Defense Witness Immunity-A "Fresh" Look at the Compulsory Process Clause, 43 LA. L. Rev. 239, 240 (1982); see also Westen, The Compulsory Process Clause, 73 Mich. L. REv. 71,74 (1974).

120. 388 U.S. 14 (1967).

121. Id. at 23.

122. Id. at 15 .

123. Id. at $15-16$. 
in fact tried to persuade him to leave the girlfriend's house and that Washington had fled the scene before Fuller fired the fatal shot. Because Fuller was convicted and sentenced for the same crime, he was barred from testifying by a Texas statute preventing coparticipants in a crime from testifying for one another. ${ }^{124}$

In holding that Washington had been demied his right to compulsory process, ${ }^{125}$ Chief Justice Warren extended compulsory process beyond the mere production of witnesses to imclude the defendant's right to have his witnesses heard. ${ }^{126}$ The Court construed the compulsory process clause as preventing the government from "arbitrarily" preventing witnesses from testifying for the defense. ${ }^{127}$ The Texas statute assumed, in accordance with the common law, that codefendants would make unrehable witnesses because they would want to protect each other from prosecution. In essence, the rule was designed to minimize instances of perjury. While the Court did not find that these assumptions were irrational, it held that the policy agamst perjury was arbitrary because it used means which were too drastic under the circumstances. ${ }^{128}$ The Court thus implied that although the state had a legitimate interest in avoiding perjured testimony, the disqualification of witnesses in this case would impose an onerous and uimecessary burden on the defendant's interest im presenting witnesses. ${ }^{129}$

\section{The Constitutional Right to Compel Defense Witness Immunity}

Applying the constitutional principles set out above, certain federal courts have acknowledged the need for a judicial grant of defense witness immunity when necessary to ensure that exculpatory evidence will be brought to hight. ${ }^{130}$ The Third Circuit has been particularly receptive to the possibility of granting judicial use immunity to defense witnesses in order to preserve fundamental fairness at trial. ${ }^{131}$ The need for such judicial immunity is not triggered by prosecutorial misconduct nor by any intentional prosecutorial distortion of the trial process. Rather, the need for immunity is grounded in the notion that a fair trial calmot result where the defendant is prevented from introducing exculpatory

124. There was no bar to a codefendant testifying for the state. Id. at 16-17 (citing Rangel v. State, 22 Tex. App. 642, 3 S.W. 788 (1887)).

125. Id. at 23.

126. See Westen, supra note 119 , at 111.

127. Washington, 388 U.S. at 23.

128. Id. at 19-23; see also Westen, supra note 119, at 115-16.

129. See Westen, supra note 119 , at 116.

130. See, e.g., Government of Virgin Islands v. Smith, 615 F.2d 964 (3d Cir. 1980); United States v. Herman, 589 F.2d 1191 (3d Cir. 1978), cert. denied, 441 U.S. 913 (1979); United States v. Morrison, 535 F.2d 223 (3d Cir. 1976).

131. See sources cited supra note 130 . 
evidence. ${ }^{132}$

In Government of Virgin Islands v. Smith, ${ }^{133}$ the Third Circuit granted judicial use immurnity to a defense witness in order to protect a defendant's due process right to present exculpatory evidence. The defendants in Smith sought to introduce the testimony of Ernesto Sanchez, whose stateinents to the police implicating himself and three others as perpetrators of the crime in question had exculpated the defendants. ${ }^{134}$ When called to the stand by the defense, Sanchez invoked his fifth amendinent privilege against self-incrimination. Defense counsel then sought a grant of use immuinty from the prosecution so that Sanchez could testify without fear of prosecution. The Virgin Islands Attorney General's office, which had exclusive jurisdiction over Sanchez, offered to grant immunity contimgent upon the consent of the United States Attorney. ${ }^{135}$ For reasons not apparent in the decision, consent was never granted. Accordingly, the exculpatory evidence was never admitted at trial, and tlie defendants were convicted and sentenced to prison.

Writing for a unanimous panel, Judge Garth held that in cases where the government can present no strong countervailing interest, a court possesses inherent authority (when certain conditions are inet) to immunize a witness who is capable of providing clearly exculpatory evidence on behalf of a defendant. ${ }^{136}$ These conditions include the filing of an application with the district court, the availability of the witness, and a convincing showing by the defendant that the witness' testimony will be "both clearly exculpatory and essential to the defendant's case." 137 Immunity would be denied, the court noted, if the proffered testimony was found to be ambiguous, cumulative, not clearly exculpatory, or relating only to the credibility of the government's witness. ${ }^{138}$

It is important to note, however, that the inajority of federal circuit courts have refused either to grant judicial use iminunity or to coinpel the prosecution to immunize witnesses. ${ }^{139}$ The inain rationale offered for

132. See Vingin Islands, 615 F.2d at 974.

133. 615 F.2d 964 (3d Cir. 1980).

134. Id. at 967.

135. The record showed that the Virgin Islands Attorney General was only requesting the U.S. Attorney's consent as a prosecutorial courtesy. Id.

136. Id. at $973-74$.

137. Id. at 972 .

138. Id. (footnote omitted) (noting that the standards formulated by the court take into account objections to judicial immunity recently expressed by other courts of appeal).

139. See, e.g., United States v. Pennell, 737 F.2d 521 (6th Cir. 1984) (federal courts have no inherent power to grant immumity to witnesses who assert their fifth amendment privilege not to testify), cert. denied, 469 U.S. 1158 (1985); United States v. Hunter, 672 F.2d 815 (10th Cir. 1982) (only the state has the authority to grant immunity, not the courts); United States v. Karas, 624 F.2d 500, 505 (4th Cir. 1980) (district court has no authority to confer immunity sua sponte), cert. denied, 
this refusal is that a judicial grant would impede the state's ability to prosecute the immunized witness. ${ }^{140}$ Because immunity implicates the executive function of deciding whom to prosecute, most courts beheve that judicial immunity violates the Constitution's separation of powers doctrine. ${ }^{141}$ Anotlier rationale for refusing to grant such immunity is thliat a defendant "suspected of crime should not be empowered to give his co-confederates an immunity batl1." 142 In otlier words, "defense witness immumity could create opportunities for undermining the administration of justice by inviting cooperative perjury anıong law violators." 143

However, even within tliose circuits rejecting defense witness immunity, soine courts, by limiting their loldings to the particular facts of the case, liave implicitly recognized that there are situations where defense witness immunity would be necessary to protect a defendant's riglit to a fair trial. ${ }^{144}$ Thus, despite tlieir reluctance to grant or conipel immunity, thiere is a "judicial reluctance to say "never." "145

449 U.S. 1078 (1981); In re Daley, 549 F.2d 469 (7th Cir.) (federal court cannot grant immunity on its initiative), cert. denied, 434 U.S. 829 (1977).

140. See, e.g., Pennell, 737 F.2d at 527-28; Earl v. United States, 361 F.2d 531, 534 (D.C. Cir. 1966), cert denied, 388 U.S. 921 (1967); Note, The Sixth Amendment Right to Have Immunity Granted to Defense Witnesses, 91 HARv. L. REv. 1266, 1273 (1978).

141. See, e.g., United States v. Capozzi, 883 F.2d 608 (8th Cir. 1989) ("Every court of appeals which has considered the question has rejected [judicial use immurity] as being a violation of the doctrine of separation of powers."); Earl, 361 F.2d at 534; Note, supra note 140, at 1273.

142. Government of Virgin Islands v. Smith, 615 F.2d 964, 973 (3d Cir. 1980) (quoting In re Kilgo, 484 F.2d 1215, 1222 (4th Cir. 1973)).

143. United States v. Turkish, 623 F.2d 769, 775 (2d Cir. 1980), cert. denied, 449 U.S. 1077 (1981)

144. See id. at 777 ("Without precluding the possibility of sone circumstances not now anticipated, we siniply do not find in the Due Process Clause a general requirement that defense witness immunity nuust be ordered wherever it seenis fair to grant it."); see also United States v. Tindle, 808 F.2d 319, 326 (4th Cir. 1986) (district court did not err in failing to immunize a defense witness "in light of the generally accepted view that a defendant has no right to witness immunity" and because defendant failed to denıonstrate that the witness' testimony would have been material, exculpatory, and unavailable from another source); Pennell, 737 F.2d at 528 (6th Cir. 1984) (after holding that the court had no inherent power to imnunize a defense witness, the court held in the alternative that even if it had the power to grant immunity, the facts of the case did not warrant it because the testimony at issue went merely to credibility, would have been cumulative, and was, at best, marginally exculpatory); United States v. Condo, 741 F.2d 238 (9th Cir. 1984) (district judge properly refused to grant immunity to certain defense witnesses where the witnesses were theniselves targets of prosecutorial investigation and the refusal to grant imnunity did not deprive defendant of a fair trial), cert. denied, 469 U.S. 1164 (1985); Earl, 361 F.2d at 534 n.1 (D.C. Cir. 1960) (stating that, although statute at issue did not authorize judicial grants of use inınunity, "[w]e inight have quite different, and more difficult, problenı" had the governnent granted immunity to prosecution witnesses but not to defense witnesses), cert. denied, 388 US. 921 (1967). See generally Annotation, Right of a Defendant in a Criminal Proceeding to Have Immunity from Prosecution Granted to Defense Witness, 4 A.L.R. 4th 617 (1981).

145. Turkish, 623 F.2d at 777. 


\section{Constitutional Rights in Postconviction Proceedings}

A state has no constitutional duty to provide a convicted defendant with postconviction remedies. ${ }^{146}$ However, the Supreme Court has recognized that once a state creates a right to discretionary review, it must comply with the dictates of the Constitution in conducting proceedings based on that right. ${ }^{147}$

In Evitts v. Lucey, ${ }^{148}$ the Supreme Court addressed whether the due process clause of the fourteenth amendment gnarantees a criminal defendant the right to effective assistance of counsel on his first appeal as of right. ${ }^{149}$ Opposing such assistance, petitioners argued that because the state had no duty to estabhish a system of as-of-right appeals, it was not bound by the Constitution in its administration of such a system. ${ }^{150}$ In other words, because it did not have the duty to provide an appeal at all, its refusal to grant the defendant an appeal because of his attorney's incompetence would be permissible under the due process clause. ${ }^{151}$

In refuting the petitioner's argument, the Court stated that " $[\mathrm{t}] \mathrm{he}$ right to appeal would be unique among state actions if it could be withdrawn without consideration of apphicable due process norms." 152 The Court then provided examples of other situations in which a state, although under no duty to provide a given right, must comport with due process in the administration of the created right. For example, although a state has no duty to implement any given welfare program, it must operate any programs it does estabhish in compliance with the due process clause. ${ }^{153}$ Moreover, although a state has great discretion in creatmg pohieies governing parole decisions, it must nonetheless develop those policies in accord with the due process clause. ${ }^{154}$ "In short, when a State

146. McKane v. Durston, 153 U.S. 684 (1894) (Constitution does not require the states to grant appeals to defendants seeking review of trial court errors).

147. See, e.g., Gardner v. California, 393 U.S. 367 (1969) (state's refusal to provide transcript of lower court opinion at no charge to indigent defendant seeking habeas corpus relief deprived him of due process); Long v. District Court, 385 U.S. 192 (1966) (Iowa's refusal to provide free transcript to indigent defendant involved in postconviction proceedings violated principles of equal protection); Smith v. Bennett, 365 U.S. 708, 713-14 (1961) (once a state creates a statutory right to habeas corpus, it cannot make distinctions based on the financial ability of the prisoner).

148. 469 U.S. 387 (1984).

149. Id. at 400-01. An "appeal as of right" is one the state provides autounatically. A "discretionary appeal" is an appeal that the court may or may not entertain depending on whether the convicted defendant ineets the requirements of the statute. In California, habeas corpus proceedings are discretionary proceedings.

150. Id. at 400 .

151. Id.

152. Id. at $400-01$.

153. Id. at 401 (citing Goldberg v. Kelly, 397 U.S. 254, 262 (1970)).

154. Id. (citing Morrissey v. Brewer, 408 U.S. 471, $481-84$ (1972); Graham v. Richardson, 403 U.S. 365, 374 (1971); Bell v. Burson, 402 U.S. 535, 539 (1971); Sherbert v. Verner, 374 U.S. 398, 404 (1963); Joint Anti-Fascist Refugee Coinn. v. McGrath, 341 U.S. 123, 165-66 (1951) (Frankfurter, J., concurring)). 
opts to act in a field where its action has significant discretionary elements, it inust nonetheless act in accord with the dictates of the Constitution-and, in particular, in accord with the due process clause."15s

In California, the prisoner's right to habeas corpus rehef is delineated by California statute. It is clear, therefore, that within such proceedings the defendant must be accorded due process under the Constitution. 156

\section{E. Application of Judicial Use Immunity to Jailhouse Informants in Habeas Proceedings}

This Section argues that courts should grant use immumity to any jailhouse informant who invokes his fifth amendment privilege within a habeas corpus proceeding instituted to challenge a prisoner's conviction on the basis of the informant's false testimony.

Once the state creates a right to habeas corpus rehef, it inust conduct the statutory proceedings in accordance with the fundamental fairness requirements of the due process clause. A court's failure to grant a jailhouse infornrant immunity in California habeas proceedings based on false evidence would violate the prisoner's constitutional rights unless a legitimate state interest outweighs the defendant's interest in presenting exculpatory evidence. ${ }^{157}$

This Section will argue that two important state interests typically implicated in a grant of defense witness immunity are absent froin the jailhouse informant situation. Thus, the state's sole remaining interest is

155. Id.

156. The Supreme Court has not delineated any other inperative constitutional rights in statecreated postconviction proceedings. The Court has held that a state's invidious discrimination on the basis of wealth in habeas corpus proceedings violates not only the due process clause but also the equal protection clause. See cases cited supra note 147. However, the Court has also held that the sixth amendinent right to counsel, although applicable to the first as-of-right appeal, does not attach in discretionary postconviction proceedings. Ross v. Moffitt, 417 U.S. 600 (1974); Douglas v. California, 372 U.S. 353 (1963); see also Pennsylvania v. Finley, 481 U.S. 551 (1986).

157. See supra notes $112-29$ and accompanying text; see also Murray v. Giarratano, $109 \mathrm{~S}$. Ct. 2765, 2781 (1989) (Stevens, J., dissenting) (death-row inmate has a fourteenth amendinent right to counsel for postconviction petitions unless the state can assert an interest outweighing the inmate's right to legal assistance).

Convictious based on perjured testimony do not violate due process unless the state introduced the perjured testinnony knowing it to be false. See, e.g., Silverman v. United States, 556 F.2d 655 (2d Cir.), cert. denied, 434 U.S. 956 (1977); Burks v. Egeler, 512 F.2d 221, 224-26 (6th Cir.), cert. denied, 423 U.S. 937 (1975). It is the knowledgeable and deliberate use of false evidence by the state which raises such use to the level of a due process violation. See Gighio v. United States, 405 U.S. 150 (1972); Napue v. Illinois, 360 U.S. 264 (1959); Alcorta v. Texas, 355 U.S. 28 (1957); Mooney v. Holahan, 294 U.S. 103 (1935). (If the informant can prove that the prosecutor knew of the false nature of the testinnony at the time it was introduced, he unay attack his conviction under a theory of prosecutorial misconduct. See supra note 99.) 
in prosecuting the jailhouse informant for perjury. The prisoner's interest in presenting exculpatory evidence so clearly outweighs the state's interest in preventing perjury that the prisoner should prevail.

\section{The Prisoner's Interest}

The prisoner's interest in the jailhouse informant context is in the presentation, at a habeas corpus proceeding, of inaterial and exculpatory evidence which could lead to a new trial. Generally a prisoner can succeed ouly if the informant admits to having perjured himself at the original trial. Because the informant is not likely to testify without a grant of use immunity, ${ }^{158}$ the prisoner is prevented from introducing niaterial and exculpatory evidence. In fact, he is deprived entirely of a inechanisin for challenging the legality of his original trial.

\section{The Prosecution's Interest}

Traditionally, courts have advanced two justifications for the state's refusal to grant immunity to defense witnesses. The first is a separation of powers concern - that any attempt by the courts to regulate the grants of immunity would encroach upon the prosecutor's discretion in choosing which criminals to prosecute. ${ }^{159}$ The second justification is that immunity grants would allow codefendants to exonerate each other by falsely accepting sole responsibility for a crime. ${ }^{160}$ Because each codefendant would be immune from prosecution, he would be "secure in his knowledge that his admission could not be used at his own trial for the substantive offense."161

Closely related to the "codefendant immunity bath" concern is the concern that an mdividual immunized witness will protect himself from prosecution by broadening the scope of his answers on the stand to include offenses which are not at issue. ${ }^{162}$ In this scenario, the state would be prevented fron prosecuting the witness for any offense that he happens to mention while under the grant of immunity.

The first justification for denying use immunity-the impingement upon prosecutorial discretion-has lost force since the Supreme Court, in

158. See supra note 91 and accompanying text.

159. See sources cited supra note 141.

160. See supra note 142; see also Bauer, Reflections on the Role of Statutory Immunity in the Criminal Justice System, 67 J. CRIM. L. \& CRIMINologY 143, 152 (1976) ("If the power to grant immunity were given to defendants, what would prevent them from showering their codefendants with immumity grants in order to "beat the rap'?").

161. United States v. Turkish, 623 F.2d 769, 775 (2d Cir. 1980), cert. denied, 449 U.S. 1077 (1981); see also Note, Case Against a Right to Defense Witness Immunity, 83 CoLUM. L. REv. 139, $139-40$ (1983).

162. Turkish, 623 F.2d at 775. 
Kastigar v. United States, ${ }^{163}$ held that use immunity satisfies a witness' right to invoke his privilege against self-incrimination. ${ }^{164}$ Before Kastigar, when a witness invoked his fifth amendinent privilege, a court could not compel his testimony without a grant of transactional immunity. Under transactional immunity, no transaction (usually criminal activity) about which the witness testified could be the subject of a future prosecution of the witness. A grant of use immunity, however, does not prevent the state from subsequently prosecuting a witness for the activity about which he testifies. Instead, it simply prevents the state from using information obtained from the immunized testimony, or any fruits thereof, in a subsequent prosecution. Thus, if the court grants a witness use immunity, the state is arguably in the same position it would be in if the witness had claimed his privilege and refused to testify. ${ }^{165}$

Commentators ${ }^{166}$ and courts ${ }^{167}$ have argued that use immumity does not always leave the prosecution im the same position as if the witness had invoked his privilege. They correctly recognize that the prosecution inay later have difficulty proving that evidence used in a subsequent prosecution was not somehow traceable to the immunized testimony. This problen, however, does not exist in the jailhouse informant scenario. The informant's admission is generally the only way to prove that he lied in his previous testimony. ${ }^{168}$ Because the state cannot obtain the informant's admission without a grant of immunity, the state's position remains unchanged by the grant of immunity. Thus, tle court is not encroaching at all upon the prosecution's discretion to prosecute the informant.

There is another element of the jailhouse informant situation which diminishes the prosecutorial discretion arguinent. In the average case, the arguinent goes, the state chooses whom it will prosecute. The state nray choose to immunize one witness in order for the state to convict another. However, the present situation does not include the normal weighing of considerations which leads the state to value one conviction over another. Instead, it is a situation where a person has already been convicted. The legality of this conviction is in question. The choice, therefore, is between the defendant's right to challenge an illegal conviction and the state's interest in prosecuting the one responsible for that

163. 406 U.S. 441 (1972).

164. Id. at 453; see Gardner, When Defense Witnesses Take the Fifth: Making the Best of a Bad Situation, CAL. ATT'YS FOR CRIM. JUST. ForUM MAG., Nov./Dec. 1988 at 13, 17; Note, supra note 14 , at 81.

165. Kastigar, 406 U.S. at 462.

166. See Note, supra note 161, at 139-40; Note, The Sixth Amendment Right to Have Use Immunity Granted to Defense Witnesses, 91 HARV. L. REv. 1266, 1274 (1978).

167. See United States v. Thevis, 665 F.2d 616 (5th Cir.), cert. denied, 459 U.S. 825 (1982); United States v. Turkish, 623 F.2d 769, $775-76$ (2d Cir. 1980), cert. denied, 449 U.S. 1077 (1981).

168. For a discussion of why the informant's admission is hikely to be the only grounds for a perjury prosecution, see supra note 91. 
conviction. Whereas the usual choice between two state actions hes with the state, the balancing of a defendant's rights against a state interest traditionally hes with the court. Thus, a judicial grant of use innunity in the jailhouse informant situation does not impede any state prosecutorial interest.

The second justification for the state's refusal to grant defense witness immunity - the risk of an immunity bath-is equally inapposite in the jailhouse informant context. First, there is no risk here that codefendants will immunize one another and then confess to the crine in each other's respective trials. Rather, the issue at hand is whether to grant immunity to an informant who had no relation to the crime at all.

Second, the fear that the witness will imnunize himself fron prosecution for unrelated crimes by giving overinclusive answers on the witness stand is also diminished by the availability of use immunity. ${ }^{169}$ Unlike transactional immumity, use immunity does not prevent the state froin prosecuting a witness for acts about which he testifies. It is unlikely, therefore, that a witness would admit to a wholly separate offense within the habeas proceeding and risk a later prosecution.

Because the two traditional justifications for refusing a grant of judicial immunity are mapphicable to the informant situation, the only reniaining state interest is in prosecuting the informant for perjury.

\section{The Defendant's Constitutional Interests Outweigh the State's Interest in a Prosecution for Perjury}

Perjury has always been considered "one of the nost odious crinnes in our law." 170 This conception is due, in part, to the threat that perjury poses to the fair administration of justice. ${ }^{171}$ Yet, despite the disdain which our criminal justice systein has for the crime, successful perjury prosecutions are uncommon and the penalty for perjury is substantially lower than for inost serious substantive crimes. ${ }^{172}$ In fact, cominentators have recognized that in the average defense witness immunity case, a court should "be inore willing to grant imnuumity for prior perjury than for other substantive crimes because perjury will probably be a less serious offense." 173 Thus, although the state's interest in prosecuting an

169. Note, supra note 161 , at 139-40.

170. Gershman, The "Perjury Trap," 129 U. PA. L. REV. 624, 636 (1981).

171. Id.

172. United States v. Turkish, 623 F.2d 769, 775 (2d Cir. 1980), cert. denied, 449 U.S. 1077 (1981); People v. Sutter, 134 Cal. App. 3d 806, 817, 184 Cal. Rptr. 829, 835 (1982) (quoting United States v. Thevis, 665 F.2d 616, 640 n.27 (5th Cir.), cert. denied, 459 U.S. 825 (1982)).

173. Note, Defense Witness Immunity in New York, 71 CoRNell L. REv. 890, 913 (1986); see also People v. Preister, 98 A.D.2d 820, 821, 470 N.Y.S.2d 478, 480 (1983) (district attorney abused his discretion in refusing to grant immunity to a prosecution witness who subsequently recanted her testiniony and would have testified on the defendant's behalf); People v. Gonzales, 120 Misc. 2d 62, 
informant for perjury is a valid one, courts are generally willing to subordinate perjury prosecutions to other important interests.

Against the state interest in perjury prosecutions we must balance the interest of the prisoner. Convicted on the basis of perjured testinony, the prisoner now seeks to expose this illegality through a writ of habeas corpus. In the name of prosecuting the informant for perjury, however, the state is restricting the prisoner's ability to present inaterial and exculpatory evidence, and is thus punishing the exact person the perjury statutes are implemented to protect.

This balance undoubtedly weighs in the defendant's favor. The foundation of our criminal justice system is the notion that it is better to let one hundred guilty people go free than to convict one innocent. In light of this core primciple, the prisoner must have the opportunity to expose illegalities in the trial process-even at the expense of immunizing an informant from a perjury prosecution. Any other finding would favor prosecutions over legitimate convictions, a notion antithetical to our constitutional primciples.

In sum, although the state has a compelling interest in preventing perjury, the defendant's interest in presenting exculpatory evidence at his habeas corpus proceeding outweighs the state's interest. Thus, the court inust grant judicial use immunity to jailhouse informants who have allegedly perjured themselves at the prisoner's trial. Only through such a grant of iminunity will the defendant's constitutional rights to fundamental fairness in a habeas corpus proceeding be properly protected.

\section{CONCLUSION}

In the Los Angeles area alone there are at least 120 United States citizens convicted of serious felonies in part on the basis of jailhouse informant testimony. There is conclusive evidence that the testimony of niany of these informants was perjured. In order to overturn these convictions, the informants must be granted immunity froin perjury. The California courts have the authority to decree such immunity. Unless they exercise this authority, they will abandon not only precedent but the entire foundation of the criminal justice systen: the defendant's right to a fair trial.

66, 465 N.Y.S.2d 471, 474 (1983) (refusing an inmunity grant because the innnunity request was in prosecution for a substantive crime rather than simply for past perjury). 
